\title{
PELAGIC BIODIVERSITY AND BIOGEOGRAPHY AROUND THE SOUTHAMERICAN CONTINENT
}

\author{
BIODIVERSIDAD PELAGICA Y BIOGEOGRAFIA EN TORNO DEL \\ CONTINENTE SUDAMERICANO
}

\author{
Annelies C. Pierrot-Bults \\ Zoological Museum, University of Amsterdam, P.O. Box 94766, 1090 GT Amsterdam, The Netherlands \\ e-mail: pierrot@science.uva.nl
}

\begin{abstract}
Biogeography around South America is well documented on the Atlantic side and less well documented on the Pacific side especially south of about $30^{\circ} \mathrm{S}$. The South Pacific oceanic areas are the least known of all pelagic areas. The different approaches to determine biogeographic provinces (e.g. the classical one showing mainly latitudinal and watermass distribution patterns based on presence/absence of species; and the biogeochemical approach based on productivity regimes and modelling) are discussed. The latter shows more east-west division. Testing of these concepts will probably reveal more coastal provinces in the Pacific area. The transitional area in the South Pacific is also an interesting area for molecular species research because there are some joint species with the Atlantic Ocean species that are not often found in the southern Indian Ocean.
\end{abstract}

KEYwords: Pelagic biodiversity, biogeography, South America.

\section{RESUMEN}

La biogeografía en torno de América del Sur está bien documentada en el lado Atlántico y menos documentada en el Pacífico, especialmente al sur de $\operatorname{los} 30^{\circ} \mathrm{S}$. Las áreas oceánicas del Pacífico Sur son las menos conocidas de todas las áreas pelágicas. Se discute los diversos intentos para determinar las provincias biogeográficas, e.g. el clásico que muestra los principales patrones de distribución latitudinal y de masas de agua basados en la presencia/ausencia de especies, y del método biogeoquímico basado en regímenes de productividad y modelamiento. El último muestra una división más este-oeste. La prueba de estos conceptos revelará probablemente más provincias costeras en el área del Pacífico. El área de transición en el Pacífico Sur, también es un área interesante para la investigación molecular de las especies porque hay un número de especies comunes con el Océano Atlántico, especies que no se presentan a menudo en el Océano Índico del Sur.

Palabras claves: Biodiversidad pelágica, biogeografía, América del Sur.

\section{INTRODUCTION}

Pelagic species are widely distributed in a horizontal plane and have three-dimensional distributions, since the sea covers about $70 \%$ of the surface of the earth and is on average four km deep. The classical biogeography is chiefly based on identifications and counts of special, mainly animal, groups. Major oceanographic provinces were defined on presence/ absence data and give a very broad picture of lati- tudinal belts modified by watermass distribution (Boltovskoy 1988). Underlying causes for these distributions were thought to be mainly present-day environmental parameters, taking into account historical factors such as continental drift that impact on ocean basin development and correlated speciation. The latest development is the work by Longhurst (1998a, 1998b). He partitioned the ocean into 4 ecological domains and about 50 biogeochemical provinces. 
So a meaningful concept of biogeography in the pelagic is not a question of presence - absence, but more of relative proportions of the different species related to environmental parameters, such as biogeochemical provinces. For discussions on pelagic biogeography in general, see Boltovskoy (1999), Longhurst (1998b), Pierrot-Bults et al. (1986), Pierrot-Bults \& Van der Spoel (1998), and Van der Spoel \& Heyman (1983).

Biodiversity in the pelagic is allegedly poor (Pierrot-Bults 1997, Pierrot-Bults \& Van der Spoel, in press), but the very broadly distributed species need molecular research to determine their true variation in relation with their geographic distribution patterns.

SPECIES DISTRIBUTIONS AND ENDEMISM.

OCEANIC FAUNA

The oceanic realm has a quite uniform fauna of pelagic species throughout the tropical and subtropical waters looking at presence/absence data. The uniformity of the species composition found in these waters is, for a considerable part, the result of the uniformity of the mesopelagic fauna. For example, in Chaetognaths, the number of oceanic species found between $0-1000 \mathrm{~m}$ in subtropical and transitional waters in the N-W Atlantic (18) (Pierrot-Bults 1982) compared with those found in the S-E Pacific (21) (Fagetti 1968) show 17 species which are the same and 1 species which only occurs in the Pacific, whereas 3 species are (sub)Antarctic. Only one species occurs solely in the Atlantic.

Endemic oceanic species, meaning species confined to one province, are rare or non-existent in these oceanic waters; the only examples I know of are (sub) Antarctic species.

\section{NERITIC FAUNA}

The strict neritic part of the pelagic ocean is situated above the continental shelf with a depth not exceeding $200 \mathrm{~m}$. The distant neritic area, as specified by Beklemishev et al. (1977), where species tend to spread out from the shelf without showing a midoceanic distribution, shows a different picture. For example, in the East Pacific, the shelf is narrow. Nonetheless, but the faunal provinces in the East Pacific determined by low-oxygen (Reid et al. 1978) or geochemical cycles ( Longhurst 1998b) extend far into the Pacific, both longitudinally to about 1808 and latitudinally from about $208 \mathrm{~N}$ to $208 \mathrm{~S}$. They show a special fauna such as the chaetognath Sagitta bierii (Pierrot-Bults \& Nair 1991), the euphausiid
Euphausia distinguenda (Brinton 1962) or the copepod Eucalanus inermis (Fleminger \& Hulsemann 1973).

Neritic species have distributional ranges which are much less extensive than oceanic ranges. Within the neritic area, we encounter a large variability in environmental parameters such as temperature, salinity, and coastal topography enabling speciation in different geographical locations. We find pelagic endemic species in the neritic areas.

\section{BIOGEOGRAPHICAL PROVINCES}

Classically, biogeographical provinces were divided into a warm water and a coldwater domain with associated species and transitional areas in between (Boltovskoy 1988). These faunal regions were mainly determined by physical watermass properties and research is mainly done by describing presence and absence of species in specific groups. These large scale patterns were based on an extensive extrapolation of spot observations.

The biogeography and faunal boundaries, as proposed by Longhurst (1998a, 1988b), are based on satellite observations and modelling of productivity regimes. He proposed four domains, e.g. Polar, Westerlies, Trade Winds, and Coastal and about 56 biogeochemical provinces. These provinces are based on epipelagic distribution of geochemical properties. The biogeography of the deeper layers is, however, closely linked to these epipelagic layers because of the vertical food chain.

One big difference between the classical biogeographical provinces and those of Longhurst is more eastwest division in Longhurst's work.

Faunal provinces are biologically distinct areas. Species are dominant in one system and rare in another so only presence/absence data or only dominant species research is insufficient to determine either the provinces or ecosystem functioning in these different parts of the world's oceans.

The results of the North Atlantic CPR (Continuous Plankton Recorder) samples of epipelagic copepod species richness and their individual distributions did not show the provinces, but a statistical analysis of the assemblages taking into account abundance data showed a clear picture of geographical distinct faunal assemblages resembling the boundaries as described by Longhurst (1998b) including his eastwest distinction in the North Atlantic (Fig. 1, Beaugrand et al. 2002). 


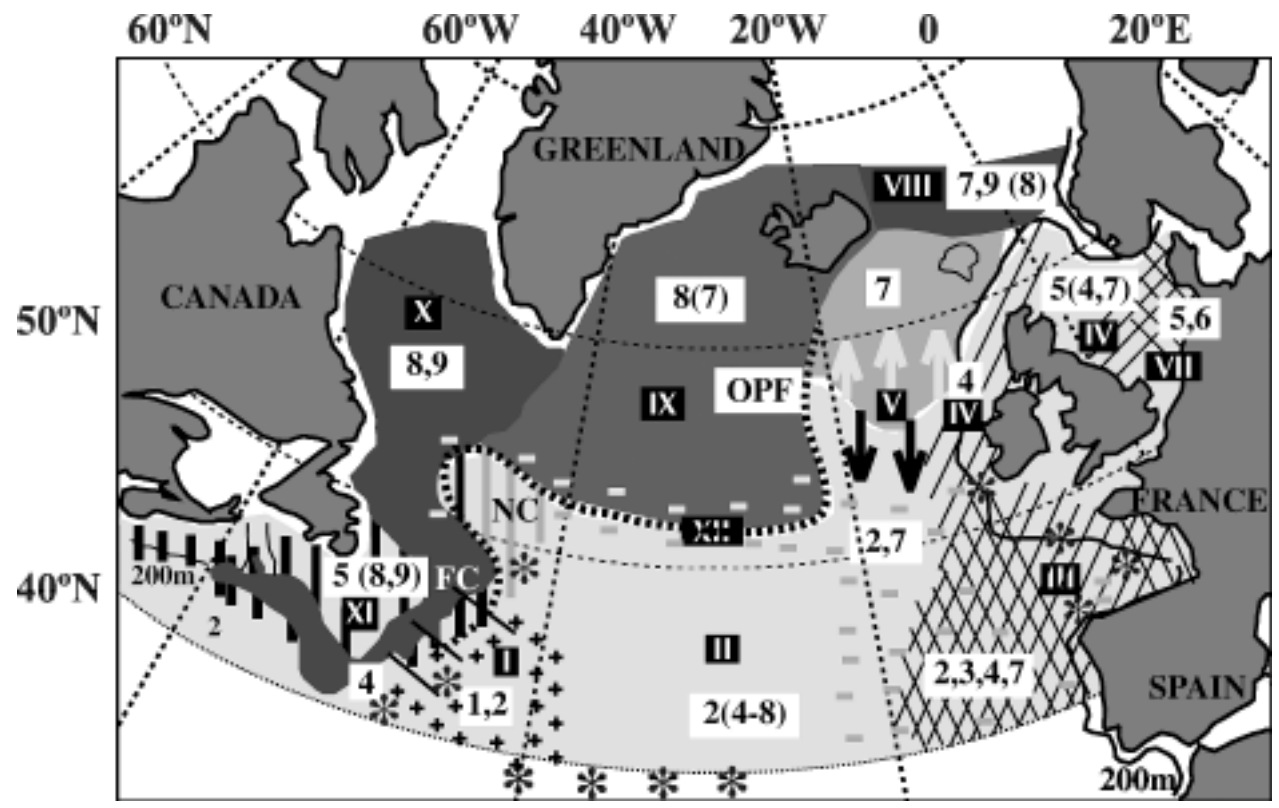

FIGURE 1. Copepod assemblages in the CPR samples in the North Atlantic Ocean (after Beaugrand et al. 2002).

Figura 1. Las asociaciones de copépodos en las muestras CPR en el Atlántico Norte (según Beaugrand, et al. 2002).

These results show that in order to come to a meaningful conclusion about biogeography we need data on species richness combined with data on abundance and biomass.

\section{BIOGEOGRAPHIC PROVINCES AROUND SOUTHAMERICA}

About the Southeast Pacific biogeography and biodiversity, the works of Antezana (2001), Bieri (1957) and Fagetti (1960, 1968, and 1972), Fagetti \& Fischer (1964), Ghirardelli (1997), and Reid et al. (1978) are known.

About the Southwest Atlantic, the comprehensive volumes of Boltovskoy (1999) give a good overview of plankton species plus a general discussion about biogeography in that area.

\section{South-east Pacific (Fig.2)}

In this region, Longhurst (1988a, 1988b) recognizes the Humboldt Current Coastal Province extending along most of the west coast of South America on the east bordered by the oceanic South Pacific Subtropical Gyre Province and on the south by the South Subtropical Convergence Province and the Subantarctic Ring Province. In the north, the Pacific Equatorial Divergence Province is found.

Biodiversity indicated by species richness is highest in the South Pacific Subtropical Gyre. Species richness is decreasing in the South Subtropical Convergence Province and the Subantarctic Ring Province, although in the convergence area, the mixing of different fauna's occurs so locally the species richness can be very high. As explained above for neritic areas, the Humboldt Current Coastal Province is poor in species. When compared with other coastal areas, like the Southwest Atlantic ones, a subdivision of this province based on faunal assemblages can probably be made when studied in more (latitudinal) detail.

\section{South west Atlantic (Fig. 3)}

Longhurst (1988b) here determines the provinces as Guianas Coastal Province, the Brazil Current Coastal Province and the Southwest Atlantic 
Gayana 67(2), 2003

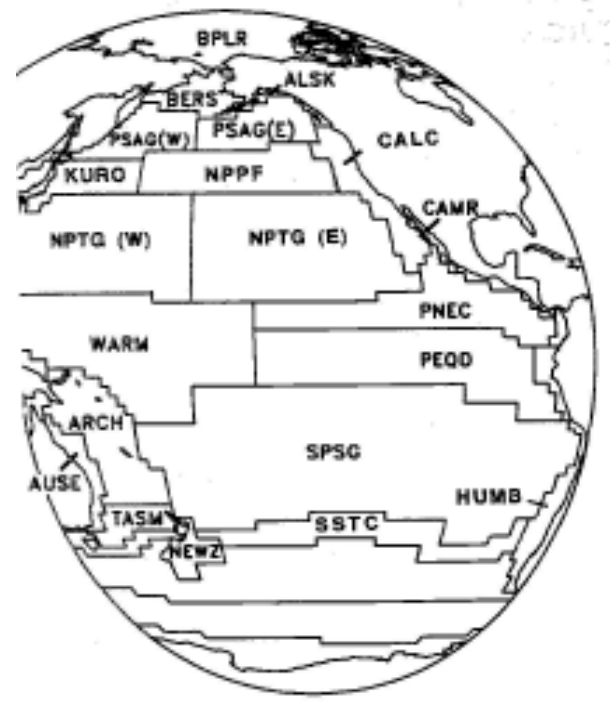

FigURE 2. Faunal provinces in the Pacific (after Longhurst 1998a, b).

Figura 2. Provincias faunísticas en el Pacífico (según Longhurst 1998a, b).

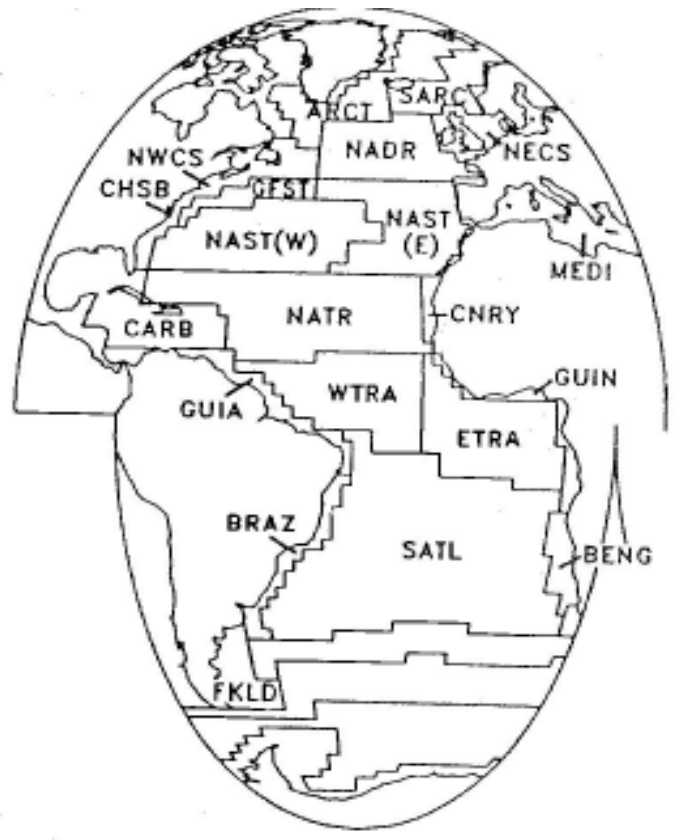

FIGURE 3. Faunal provinces in the Atlantic (after Longhurst 1998a, b).

FIgURA 3: Provincias faunísticas en el Atlántico (según Longhurst 1998a, b). 
Shelfs Province, the South Atlantic Gyral Province, the Western Tropical Atlantic Province, and again the South Subtropical Convergence Province and the Subantarctic Ring Province.

Also, species richness here is highest in the South Atlantic Gyral Province.

The coastal area is subdivided in three different areas. The South Subtropical Convergence Province and the Subantarctic Ring Province show more or less the same species as in the South Pacific because of the Circumantarctic current.

Boltovskoy et al. (1999) recognizes a finer division of the coastal areas of South America. They also point out that the transitional areas look rather large, but these boundaries are the results of the extremes of the southward distribution of warmwater species by the Brazil current and the northward distribution of coldwater species by the Malvinas (Falkland) current. At any given time, the actual area of mixing of cold and warm water fauna is much smaller and the place and time depend on the seasonal variation.
The South Pacific transitional waters show a fauna which is related to the Atlantic fauna. Several species here are not known for the southern Indian Ocean

The areas we know least about are the deeper layers of the ocean, especially the bentho-pelagic layer. Here we can expect to find new species (Casanova 1991).

\section{BIODIVERSITY}

Species richness of pelagic species shows latitudinal variation, as shown for three different groups of planktonic organisms: chaetognaths, euphausiids and pteropods as shown in Table I.

In general, when looking at species richness in a given area, we see less neritic species than in the neighbouring oceanic waters. This may be a factor of 10 less, but as said above, these oceanic species occur over the whole ocean while the neritic species show local differences (Fig. 4).

TABLE I. Species richness in the Atlantic, Pacific, and Indian Oceans, for Chaetognatha, Pteropoda, and Euphausiidae. (after Pierrot-Bults \& Nair 1997).

Tabla I. Riqueza de especies de Chaetognatha, Pteropoda y Euphausiidae (según Pierrot-Bults \& Nair 1997) en los océanos Atlántico, Pacífico e Indico.

\begin{tabular}{llllllllll}
\hline & \multicolumn{2}{c}{ Chaetognatha } & \multicolumn{3}{c}{ Pteropoda } & \multicolumn{3}{c}{ Euphausiidae } \\
& A & P & I & A & P & I & A & P & I \\
\hline Arctic & 1 & 1 & & 3 & 4 & & 5 & 5 & \\
Subarctic & 9 & 6 & & 20 & 17 & & 10 & 10 & \\
408 N-408S & 25 & 35 & 29 & 120 & 90 & 95 & 25 & 30 & 30 \\
Subantarctic & 9 & 8 & 8 & 17 & 17 & 17 & 10 & 10 & 10 \\
Antarctic & 4 & 4 & 4 & 11 & 11 & 11 & 5 & 5 & 5 \\
\hline
\end{tabular}

\section{CONCLUSIONS}

Studies of the Southern Hemisphere pelagic realm are far less numerous than those of the Northern Hemisphere. Especially the open ocean of the South Pacific is not well studied. The extensive studies of pelagic groups in the Pacific by scientists of the Scripps Institution of Oceanography concentrated on the North and Central Pacific and did not reach more than $30^{\circ} \mathrm{S}$ (Bieri 1959).

To study the different provinces and relate species to ecosystem functioning, we need to map zooplankton biomass and species composition, and study horizontal and vertical distributions. A detailed study has to be done at selected sites, for these net samples will be necessary. Coarse grid sampling in other areas can be enough to fill in the gaps. Sampling should be done as much as possible with new and fast technology, such as optical and acoustic devices. To relate these findings to the environment remote sensing should be part of a research programme.

Another gap to be addressed is the taxonomic impediment. There is a need to train people in tax- 
Gayana 67(2), 2003

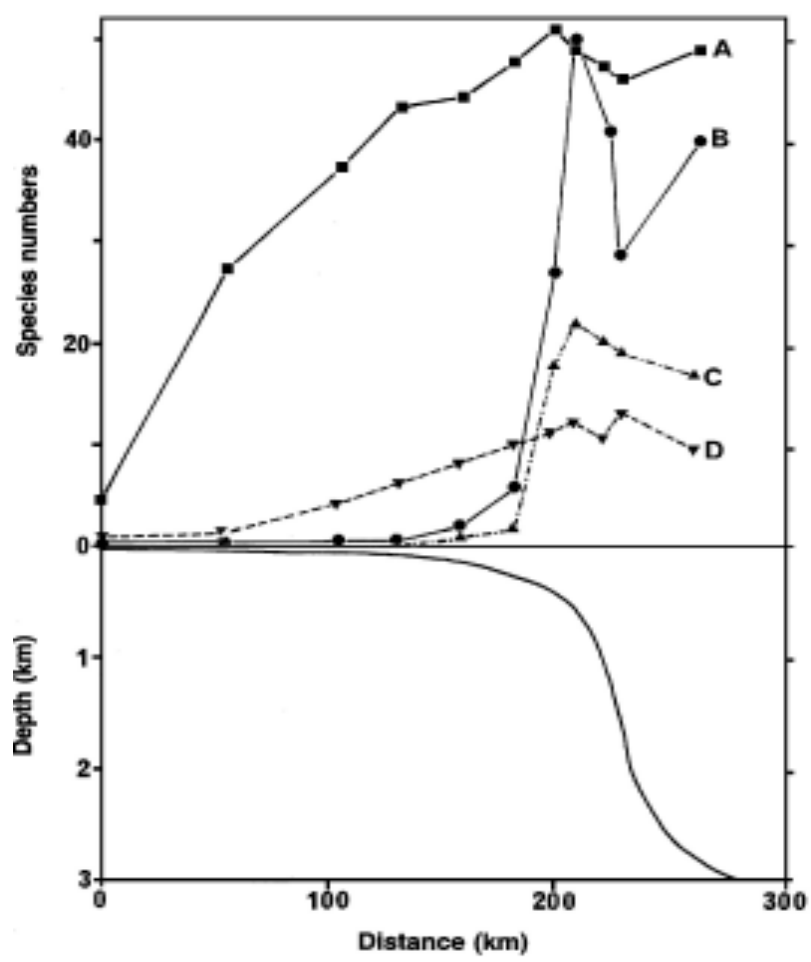

FIGURE 4. Changes in the number of pelagic species, from neritic to oceanic waters, off Florida (Gulf of Mexico). A. copepods, B. mid-water fishes, C. decapods, D. euphausiids (after Angel 1992).

Figura 4. Los cambios en el número de especies pelágicos, desde aguas neríticas a oceánicas, frente a Florida (el Golfo de México). A. copépodos, B. peces de aguas intermedias, C. decápodos, y D. eufáusidos (según Angel 1992).

onomy to be able to assess biodiversity. New tools should be developed, especially computer based identification systems.

Among others, Longhurst (1998b) says "the present state of plankton taxonomy is a hindrance to ecological geography" and McGowan (1999) states that "there have been long and frequent complaints in the past five or six years about the lack of experienced taxonomists. Universities and research institutes NSF and NOAA are all at fault here. The Census of Marine Life can correct this glaring gap".

Of no less importance is to look critically at our known species to see whether they are really the same over such large distributional areas in such different parts of the ocean (Pierrot-Bults, 1997). Why are there so few species in the pelagic compared with the benthic and with terrestrial environments?

A research programme should sample selected species for molecular work to gain insight in popula- tion genetics of planktonic species and to reveal possible cryptic species.

This will also give us also an idea about possible mechanisms of adaptation and speciation in the pelagic ocean.

\section{REFERENCES}

Angel, M.V. 1997. Pelagic biogeography. In: Ormond R.F.G., J.D. Gage \& M.V. Angel (Eds) Marine biodiversity: patterns and processes, 35-68. Cambridge University Press

Antezana, T. 2001. La biodiversidad en el ambiente pelágico: 61-84. In: Alveal K. \& T. Antezana (Eds.). Sustentabilidad de la bioversidad. Universidad de Concepción-Chile.

Beaugrand G., F. IbáÑez, J.A. Lindley \& P.C. Reid. 2002. Diversity of copepods in the North Atlantic and adjacent seas: species associations and biogeography. Marine Ecology Progress Series 232: 179-195. 
Pelagic Biodiversity: Pierrot-Bults, A.

Beklemishev, C.W., N.B. Parin \& G.N. Semina. 1977. Pelagial. In: M. Vinograodov (ed) Biogeographical structure of the Ocean-Ocean Biogeography I: 219-261. (In Russian).

BIERI, R. 1957. Chaetognath fauna off Peru in 1941. Pacific Science 11(3): 255-264.

BIERI, R. 1959. The distribution of planktonic Chaetognatha in the Pacific and their relationship to the watermasses. Limnology and Oceanography 4: 1-28.

Boltovskoy, D. 1988. Pelagic Biogeography: Background, Gaps and Trends In: A.C. PierrotBults \& S. Van der Spoel (Eds). Pelagic Biogeography ICoPB II. Proceedings of the 2nd International Conference. IOC Workshop Report 142: 53-64.

Boltovskoy, D. Ed 1999. South Atlantic Zooplankton. Volume 1: 1-868, Volume 2: 869-1706. Backhuys Publishers, Leiden.

Casanova, J.P. 1991. Chaetognaths from the Alvin dives on the seamount Volcano 7 (east tropical Pacific). Journal of Plankton Research 13(3): 539-548.

Fagetti, E.G. 1960. Nueva contribución al estudio de los quetognatos de la costas central y norte de Chile. Actas Trabajos I. Congresso sudamericana Zoologicas 1959, 21960 [1961]: 127-135.

FAgetti, E.G. 1968. Quetognatos de la expedición "Marchile I" con observaciones acerca del posible valor de algunas especies como indicadoras de las masas de agua frente a Chile. Revista de Biología Marina. Valparaíso 13: 85171.

Fagetti, E.G. 1972. Bathymetric distribution of Chaetognaths in the South Eastern Pacific Ocean. Marine Biology 17: 7-29.

Fagetti, E.G. \& W. Fischer. 1964. Resultados cuantitativos del zooplancton colectado frente a la costa Chilena por la Expedición "Marchile I'. Montemar, 11(4): 137-193.

Fleminger, A. \& K. Hulsemann. 1973. Relationship of Indian Ocean Epiplanktonic Calanoids to the World Oceans. In: B. Zeitschel \& S.A. Gerlach (Eds). The biology of the Indian Ocean: 339348. Spriner Verlag, Berlin, Heidelberg, New York.

GhIRARDELLI, E. 1997. Chaetognaths. In: L. Guglielmo
\& A. Ianora (Eds.), Atlas of marine zooplankton. Straits of Magellan. Amphipods, Euphausiids, Mysids, ostracods, and chaetognaths: 245-275. Springer Verlag Berlin, Heidelberg, New York.

LONGHURST, A. 1998A. Ecological biogeography of the pelagial. In: A.C. Pierrot-Bults \& S. Van der Spoel (Eds.), Pelagic Biogeography ICoPB II. Proceedings of the 2 nd International Conference. IOC Workshop Report 142: 239-249.

LONGHURST, A. 1998в. Ecological geography of the sea. i-xiii, 1-398 Academic Press.

McGowan, J.A. 1971. Oceanic biogeography of the Pacific: 3-74. In: BM Funnell \& WR Riedel (eds). The micropalaeontology of oceans. Cambridge at the University Press

Pierrot-Bults, A.C. 1982. Vertical distribution of Chaetognatha in the central Northwest Atlantic near Bermuda. Biological Oceanography, 2 (1): 31-61.

Pierrot-Bults, A.C. 1997. Biological diversity in oceanic macrozooplankton: more than counting species. In: Ormond R.F.G., J.D. Gage \& M.V. Angel (Eds.), Marine Biodiversity. Patterns and processes: 69-93.

Pierrot-Bults, A.C. \& V.R. Nair. 1991. Distribution patterns in Chaetognatha: 86-116. In: Q. Bone, H. Kapp \& A.C. Pierrot-Bults (Eds). The Biology of Chaetognaths. Oxford University Press.

Pierrot-Bults, A.C. \& S. VAn der Spoel. 1998. Pelagic Biogeography ICoPB II. Proceedings of the 2nd International Conference. IOC Workshop Report 142: $1-387$.

Pierrot-Bults, A.C., S. Van der Spoel, B.J. Zahuranec \& R.K. Johnson. 1986. Pelagic Biogeography. Unesco Technical Papers in Marine Science 49: 1-295.

Pierrot-Bults, A.C. \& S. Van der Spoel (in press). Macrozooplankton diversity: How much do we really know? Zoologische Verhandelingen.

Reid, J.L., E. Brinton, A. Fleminger, E.L. Venrick \& J.A. McGowan. 1978. Ocean Circulation and marine life. In: H. Charnock \& G. Deacon (Eds.). Advances in Oceanography: 65-130. Plenum Press, New York, London.

Van der Spoel, S. \& R.P. Heyman. 1983. A comparative Atlas of Zooplankton. 1-186. Bunge, Utrecht.

Fecha de recepción: 06/05/03

Fecha de aceptación: 21/09/03 